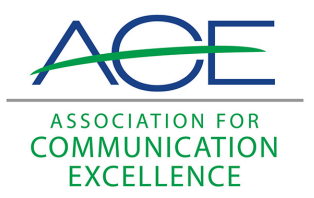

Journal of Applied Communications

\title{
The Communication Effectiveness of Scientist-Stakeholder Partnerships Addressing Agriculture and Natural Resources Issues: A Citation Analysis of the Florida Water and Climate
}

\section{Alliance}

Shuyang Qu

lowa State University

Tracy Irani

University of Florida

Angela B. Lindsey

University of Florida

Follow this and additional works at: https://newprairiepress.org/jac

Part of the Organizational Communication Commons, and the Publishing Commons

(c) (1)(2)

This work is licensed under a Creative Commons Attribution-Noncommercial-Share Alike 4.0

License.

\section{Recommended Citation}

Qu, Shuyang; Irani, Tracy; and Lindsey, Angela B. (2018) "The Communication Effectiveness of ScientistStakeholder Partnerships Addressing Agriculture and Natural Resources Issues: A Citation Analysis of the Florida Water and Climate Alliance," Journal of Applied Communications: Vol. 102: Iss. 1. https://doi.org/ 10.4148/1051-0834.1755

This Research is brought to you for free and open access by New Prairie Press. It has been accepted for inclusion in Journal of Applied Communications by an authorized administrator of New Prairie Press. For more information, please contact cads@k-state.edu. 


\title{
The Communication Effectiveness of Scientist-Stakeholder Partnerships Addressing Agriculture and Natural Resources Issues: A Citation Analysis of the Florida Water and Climate Alliance
}

\begin{abstract}
Public opinion on contentious agricultural and natural resource issues, such as climate change, has become more polarized and the science itself has sometimes been called into question. In response, academics and various types of stakeholders have formed organizational partnerships and collaborations to disseminate their science to inform the public and policy. These Scientist-Stakeholder Partnerships possess advantages such as technical expertise, however, such groups often face challenges in communicating effectively and establishing their reputation.

This study selected Florida Water and Climate Alliance (FWCA) as an example of this type of organization and used citation analysis to measure communication effectiveness and impact. The findings suggested FWCA members were productive in authoring and being cited in academic publications. Many FWCA articles were cited by other members of the organization, suggesting an organization's members can help create a body of literature around the organization's interest areas. This study demonstrated the use of citation analysis as a method of evaluating the communication effectiveness of scientist-stakeholder partnerships/self-directed organizations. To be more effective with external audiences, it is recommended that such organizations invest in developing and promoting their identity, core messages and visibility with key audiences and consider moving beyond member generated efforts to work with an agricultural communications practitioner. Future research should examine public awareness and media visibility of such organizations.
\end{abstract}

\section{Keywords}

Citation analysis, impact, issue advocacy, scientist-stakeholder partnerships, communication effectiveness, research productivity

\section{Cover Page Footnote/Acknowledgements}

This manuscript was based on research presented at the 2017 Association for Communication Excellence (ACE) annual conference in New Orleans, LA. 


\section{The Communication Effectiveness of Scientist-Stakeholder Partnerships Addressing Agriculture and Natural Resources Issues: A Citation Analysis of the Florida Water and Climate Alliance}

Issue advocacy is a concept that originated in the field of political science, where it is used to describe a political campaign or advertising that focuses on a specific issue rather than a party or a candidate (Pfau, Holbert, Szabo, \& Kaminski, 2002). A primary goal of advocating about an issue is to influence public opinion on that issue. Issue advocates typically employ forms of advocacy, including media advocacy, to exert influence on the public and media agendas (Sinclair \& Irani, 2005).

Within agricultural communications, commodity associations, environmental groups, and lobbyists are typically seen as engaging in issues advocacy with a view toward influencing public opinion and policy. They often have knowledge as to perceptions and public opinions about agricultural and natural resources issues (Schuett, Selin, \& Carr, 2001). Their efforts can be distinguished from those of academic institutions and public agencies/extension, which do not advocate but do focus on enhancing informed decision making and the "role for education to enable the individual to become a better decision maker" (Cockrel, 1997, p. 2). Although many academic and public-sector organizations focus on informing policy and decision making by providing objective, science-based information, little is known as to how effective these efforts might be, especially with respect to controversial issues.

Increasingly, public opinion on certain agricultural and natural resources (ANR) issues, such as climate change and natural resources conservation, has become more polarized and the science itself has sometimes been called into question (Boykoff \& Boykoff, 2007). Climate change is an example of a contentious issue where multiple types of individual and organizational actors, including academic scientists, laypeople, community leaders and those representing specific interest groups and social movements, have banded together in informal groups and organizations to convey scientific information through both mediated and non-mediated channels (Brulle, Carmichael, \& Jenkins 2012). Climate variability and change is particularly important to the ANR sector in that it affects the stability of food systems, as well as lack of access to potable water supplies and water resources that can be used for food production (Wheeler \& von Braun, 2013; Vörösmarty, Green, Salisbury \& Lammers, 2000). Fielding (2006) defines effective communication as communications that was interpreted by the receiver the way the sender intended. Achieving effective communication is a complex process as meanings are not simply handed down to others. Therefore, effectively communicating about complex and polarized issues, such as climate change, is important for agricultural communicators to help lay audiences and policymakers understand the needs and perspectives of agricultural producers and growers with respect to these contentious issues.

Such communication can be challenging, as the technical information related to an issue can be complicated and difficult to understand. Given this, informal partnerships of academics and stakeholders may come together to share information and educate/communicate scientific findings. Such informal partnerships often start their communication efforts with research reported in their members' most familiar and trusted resource: academic journals. This initial first step may provide information for informed decision making and broader dissemination through additional mediated and non-mediated communication channels.

Partnerships and collaborations between academics and various types of stakeholders, where those with a specific interest in an issue come together to form organizations designed to educate, 
while also seeking to inform the public and policy, are known as scientist-stakeholder partnerships (Meadow, et al., 2015; Grehan, Long, Deegan, \& O'Cinneide, 2003). These groups strive to build their public reputation to become known sources of expertise in order to make a greater impact as a group. Yet few studies have looked at how effective such loosely structured organizations are in communicating information and building their visibility and reputation.

Organizations with loosely affiliated members and little to no official structure are known as "self-directed work groups" (Kauffeld, 2006, p. 1). Organizations with self-directed members share the characteristics of a Self-Directed Work Team (SDWT) within a company or an organization. Literature indicates the SDWT model increases flexibility and responsiveness of an organization (Daft, Bettenhauser, \& Tyler, 1993; Quinn, 1992), and reduces costs (Manz \& Sims, 1995). The SDWT model is also believed to have a decentralized structure, which improves the effectiveness of manufacturing performance and organizational control over supervisory control (Banker, Field, Schroder \& Sinha, 1996; Barker, 1993).

Given the contentious nature of issues like climate change, it is perhaps not surprising that climate scientists and stakeholders have formed self-directed organizations focused on sharing the science and disseminating information about climate variability and change. Some examples of such organizations include the Water Utility Climate Alliance, Southeast Florida Regional Climate Compact, and the San Juan Climate Initiative.

Scientists and stakeholders involved in water resource allocation and/or city and regional planning may join such groups because of their beliefs in science, the importance of connecting their work to the communities they live in and the need to educate the public or their target audiences about climate science issues. Such scientist-stakeholder self-directed groups do seem to have potential benefits, such as possessing scientific and technical expertise (Center for Science and Democracy, 2016). Working as a group also fosters scientific research development and collaborations (Center for Science and Democracy, 2016). By working as a group, a broader connection can be made with the scientific community, providing opportunities to access data and build trust with local communities, increase credibility with decision makers and make the scientists' voices heard about critical scientific issues (Center for Science and Democracy, 2016).

The downside of the SDWT model for such organizations also lies in their decentralized organizational structure. Decentralized organizational structures have limited hierarchical authority; thus, they pose the challenge of using very limited hierarchical authority to reinforce organizational implementation and management (Kern \& Bulkeley, 2009). Therefore, for the scientist-stakeholder partnership, it may be more difficult to decide on and implement plans for enhancing visibility and communication effectiveness to achieve organizational goals.

\section{Conceptual Framework}

A good reputation is one of the most valuable intangible assets for a self-directed group to succeed in communicating effectively to its audiences (Park, Lee \& Kim, 2014). Organizations with a good reputation reduce stakeholder uncertainty about organizational performance, reinforce competitive advantage, and enhance their organizational image to the public (Vidaver-Cohen, 2007). Maintaining a good reputation over time builds an organization's reputation capital, which can protect the organization from a crisis situation (Jackson, 2004).

To measure organizational reputation, Lange, Lee, and Dai (2011) conducted a comprehensive literature review and summarized a three-dimensional organizational reputation measurement. The first dimension is being known, which is to what extent an organization has generalized awareness 
or visibility (Lange et al., 2011). The wider a recognition or an awareness an organization can generate among its intended stakeholders, the greater chance the organization can stand out among its competitors. Thus, the organization is more likely to achieve a positive reputation (Rindova, Williamson, Petkova, \& Sever, 2005). The second dimension is being known for something. Instead of a general awareness of the organization, the second dimension focuses on the feature of an organization that is "tightly coupled to consequences and tangible organizational outputs" (Love \& Kraatz, 2009. p. 317). Examples of such features can be a high-quality product, community responsibilities, and innovativeness (Carter, 2006). By having a distinctive feature known in the field, reputation is achieved through stakeholders' recognition of how this organization differs from others (Washington \& Zajac, 2005). The third dimension of organizational reputation is generalized favorability, meaning the degree to which an organization is considered likable and attractive (Barnett, Jermier, \& Lafferty, 2006). Generalized favorability is a nonspecific evaluative impression. Organization stakeholders and consumers interpret the organization's financial, social, environmental and cultural attributes and form an impression of the organization (Barnett et al., 2006; Highhouse, Brooks, \& Gregarus, 2009). The stakeholders and consumers perform this "affective evaluation" through "relatively stable, long-term, collective judgments" by their understanding of the organization's actions and achievements (Rhee \& Valdez, 2009, p. 146; Gioia, Schultz, \& Corley, 2000, p. 67).

Specific to organizations with scientist members, most members in scientist-stakeholder organizations have affiliations with academic or research institutes where intellectual impact is an important indicator of a scholar's credibility in the field. Therefore, research productivity becomes a critical quantitative criterion to measure the reputation of scientist-based organizations (VidaverCohen, 2007). The study of research productivity and citation impact is a long-standing tradition in academia (Serenko \& Bontis, 2004). One of the most critical indicators used to measure research productivity is publication productivity (Ramsden, 1994). Research has shown that publication productivity is often associated with an academic institution's prestige level (Borokhovich, Bricker, Brunarski, \& Simkins, 1995).

Citation impact of publications is an equally important measurement of intellectual contribution, if not more important (Ramsden, 1994). Robinson and Adler (2011) stated if a researcher had a number of publications, but none of the publications showed evidence of shaping others' thinking, the impact on others would be rated fairly low. Citation analysis is a common method used to measure research impact and thus a way to assess the reputation of a scientistbased organization (Meho, 2006). Citation analysis allows researchers to assess the degree to which scientists' work is accessed and cited by others. As such, it can indicate how effective scientists are in disseminating their findings, which is the way in which they try to build a reputation, exert influence, and inform audiences and policy.

A citation analysis is "the counting and analysis of citations in a particular publication or group of publications" (Goehlert, 1979, p. 185). Goehlert (1979) indicated that citation studies, regardless of the discipline, would typically "investigate (a) the form of publications cited, (b) the subject field distribution, (c) the languages used, (d) the age of the literature, and (e) the identification of significant sources, such as core journals" (p. 185).

\section{Purpose and Objectives}

The purpose of this project was to investigate the communication effectiveness and impact of a specific scientist-stakeholder partnership organization working in the domain of climate change 
that follows the SDWT model. Based on the literature, this study specifically looked at the research productivity and citation impact of the organization and its members. Specific objectives were to:

1. Describe the number of journal article citations of a climate science focused scientiststakeholder partnership/self-directed organization and the types and number of articles that cite members' work.

2. Describe the citation impact of members' work in terms of the journals in which members publish, the number of languages in which members publish their work and the frequency of internal citations by members.

\section{Methods}

This study used a citation analysis method focused on exploring the communications effectiveness and citation impact of the Florida Water and Climate Alliance (FWCA), a scientiststakeholder partnership located in the Southeastern U.S. A group of scientists, water resource managers, planners and researchers in water and climate-related fields in the Florida area formed FWCA in 2012. The stated mission of the FWCA is to strive to provide climate science tools and findings to inform water and climate-related decision making in Florida (The Florida Water and Climate Alliance, 2016). FWCA scientists have focused on research areas such as changes in precipitation and sea level rise. Members of FWCA strive to make contributions not only to the academic field globally, but also to a variety of audiences by conducting workshops, presenting seminars, and being a source of information in media.

FWCA was selected for five reasons: (a) it is scientist based; (b) it is a self-directed work team type of organization; (c) it advocates issues related to climate and water; (d) members of FWCA produce scholarly journal articles in the agricultural and natural sciences area; and (e) members of FWCA publish scholarly articles around the globe.

\section{Data Collection}

All FWCA members' published articles were archived on the FWCA official website. Researchers for this study collected all FWCA member published articles through the archive on FWCA official website on September 22, 2016. A total of 28 FWCA published articles were documented on this website. The publication years of the articles ranged from 2012 to 2016. The researchers identified the articles that have cited FWCA member authors and their published articles through two scholarly search tools, Google Scholar and Web of Science. Web of Science is "a comprehensive research platform database containing tools to search scholarly journals, books, proceedings, published dataset, and patents" (Clarivate Analytics, 2016, para. 2). Google Scholar is an open-access search tool for documents primarily in science and social science, "consisting of full-text journal articles, technical reports, preprints, theses, books, and other documents, including selected Web pages that are deemed to be "scholarly"' (Vine, 2006, para. 3).

\section{Data Analysis}

This study used descriptive statistics to identify the number of publications, the number of citations generated by each FWCA article, and the number of journals that published FWCA articles. Descriptive statistics provide basic descriptions and summaries of the sample and the measures of a study (Johnson \& Christensen, 2012).

When counting how many times FWCA published articles were cited in each journal, one time was operationalized to mean this FWCA article was cited in one other scholarly article from a 
journal, regardless how many times this FWCA article was referenced in this article. Specifically, for the second research objective, we searched for journals that had cited FWCA articles and showed how many times these journals cited FWCA articles. When one FWCA article is cited by multiple journal articles within one journal, it "counted" as many times as it appears in the number of journal articles. For example, Irrigation Science cited FWCA articles "two times," it could mean two different Irrigation Science articles cited the same FWCA article; it could also mean one Irrigation Science article cited two different FWCA articles; it could also mean two different Irrigation Science articles cited two different FWCA articles.

\section{Findings}

Objective 1: Describe the number of journal article citations of a climate science focused scientiststakeholder partnership/self-directed organization and the types and number of articles that cite members' work.

There are 20 regular members of the FWCA (defined as those who regularly attend the majority of the workshops and meetings of the group), including eight steering committee members. Approximately $50 \%$ are academics, working for academic institutions and/or public agencies. These FWCA members published a total of 28 peer-reviewed journal articles between 2012-2016. Out of that total, 25 were cited in other scholarly articles, with a total of 246 overall citations of FWCA members' work. The most cited FWCA article yielded 29 citations. The average number of citations of all 28 articles is $8.67(S D=6.97)$.

Table 1

Citation frequency of FWCA published articles

Article Name

Trends in precipitation and temperature in Florida, USA

Quantitative Spatiotemporal Evaluation of Dynamically Downscaled

MM5Precipitation Predictions over the Tampa Bay Region, Florida

Climate information use among southeast US water managers: Beyond barriers and toward opportunities

Forecasting Reference Evapotranspiration Using Retrospective Forecast Analogs in the Southeastern United States

One-way coupling of an integrated assessment model and a water resources model: Evaluation and implications of future changes over the US Midwest

Evaluation of dynamically downscaled reanalysis precipitation data for hydrological application

Development and comparative evaluation of a stochastic analog method to downscale daily GCM precipitation

Assessment of the utility of dynamically-downscaled regional reanalysis data to predict streamflow in west central Florida using an integrated hydrologic model

Seasonal prediction of regional reference evapotranspiration based on climate forecast system version 2 
Comparison of two analog-based downscaling methods for regional reference evapotranspiration forecasts

Early Adoption of Climate Information: Lessons Learned from South Florida Water Resource Management

Dynamic downscaling of the twentieth-century reanalysis (Misra et al. (2012 or 2013))

Projected climate change scenario over California by a regional ocean-atmosphere coupled model system

The GEFS-based daily reference evapotranspiration (ETo) forecast and its implication for water management in the southeastern United States

Thirty-two-year ocean-atmosphere coupled downscaling of global reanalysis over the Intra-American Seas

Statistical Downscaling Multimodel Forecasts for Seasonal Precipitation and

Surface Temperature over the Southeastern United States

Hydrologic impacts of future climate change on Southeast US watersheds 5

Hydrologic implications of errors in bias-corrected regional reanalysis data for west-central Florida

Pacific and Atlantic sea surface temperature influences on A119:B119 the

Apalachicola-Chattahoochee-Flint river basin

Validating climate models for computing evapotranspiration in hydrologic studies:

How relevant are climate model simulations over Florida

Reducing bias-corrected precipitation projection uncertainties: A Bayesian-based indicator-weighting approach

Assessment of alternative methods for statistically downscaling daily GCM

precipitation outputs to simulate regional streamflow

The seasonal climate predictability of the Atlantic Warm Pool and its teleconnections

Forecasts of seasonal streamflow in West-Central Florida using multiple climate predictors

Validating ENSO Teleconnections on Southeastern U.S. Winter Hydrology 2

The NOAA MAPP Climate Prediction Task Force $\quad 0$

Developing a surface water resiliency model for the 21 century 0

A level-of-service concept for planning future water supply projects under probabilistic demand and supply framework 1

Total

FWCA and member published articles were cited in 173 journal articles from 89 different journals, four books, two conference proceedings, and 10 dissertations and theses. 
Objective 2. Describe the citation impact of members' work in terms of the journals in which members publish, the number of languages in which members publish their work and the frequency of internal citations by members.

Results indicated that a total of 173 journal articles in 89 different journals have cited FWCA member published articles. The Journal of Hydrometeorology and Hydrology and Journal of Earth System Sciences cited FWCA member published articles 14 times, the highest number of citations among all other journals. The Journal of Hydrology cited FWCA member published articles 13 times. Figure 1 displays the journals that have cited FWCA articles at least twice over the fiveyear time period. Fifty-four journals had at least one of their journal articles citing one of the FWCA members' published articles. 


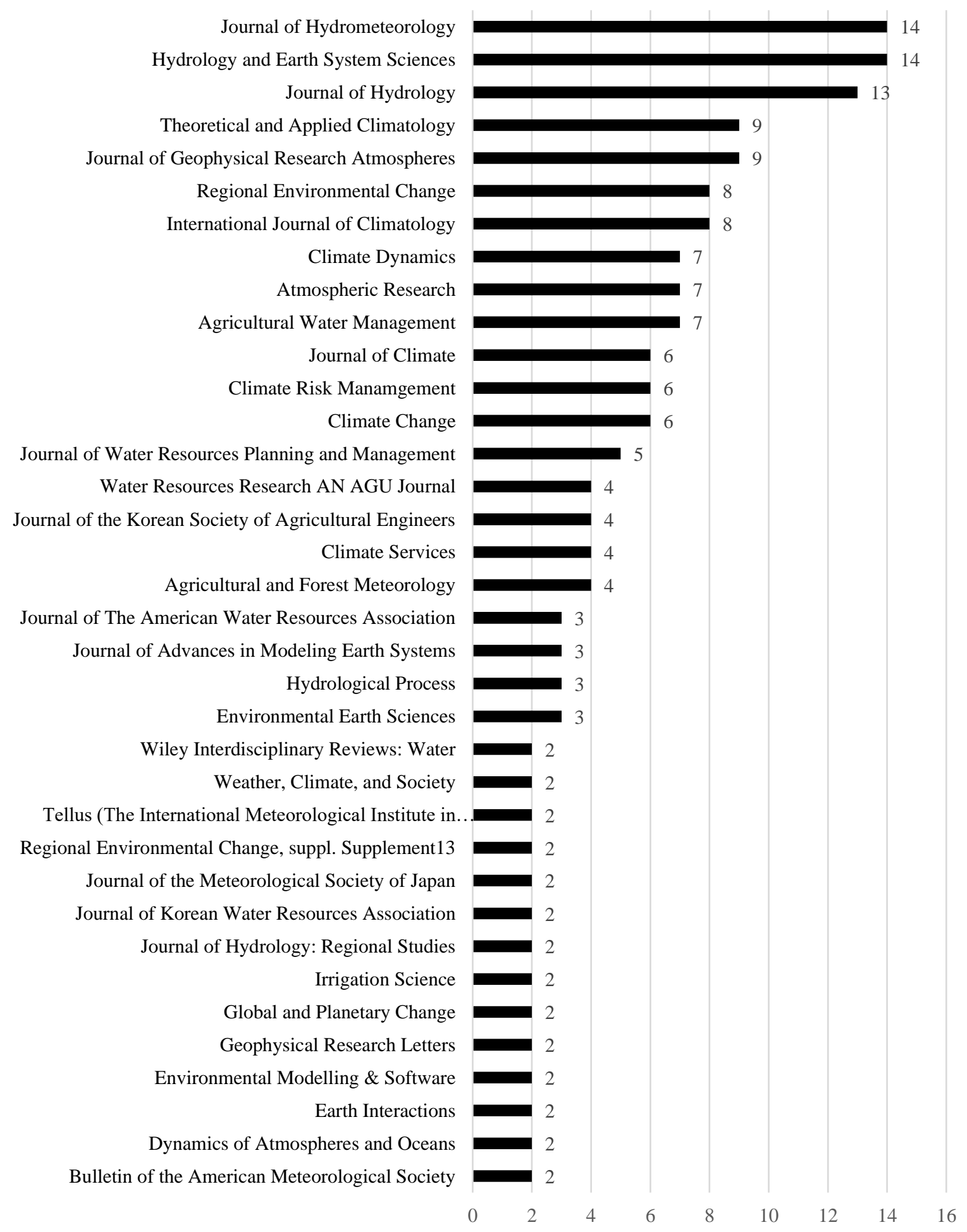

Figure 1: Journals citing FWCA published articles two or more times

The majority (81 out of 89) of these articles were published in the English language. Three of the articles are in the Chinese language, including 《南水北调》(South-to-North Water Transfers 
and Water Science \& Technology), 《气象》(Meteorological Monthly), 《节水灌溉》(Water Saving Irrigation). Two journals are in the Korean language, including 《한국농림기상학회지》 (Korean Journal of Agricultural and Forest Meteorology) and Journal of the Korea Disaster Prevention Association. One journal, named Tecnología y Ciencias del Agua is in Spanish, and two are in Portuguese, including Estudos Avançados, Pesquisa Agropecuária Brasileira (Table 2).

Table 2

Foreign Language journals citing FWCA published articles

\begin{tabular}{|c|c|}
\hline Languages & Journal Title \\
\hline \multirow[t]{6}{*}{ Chinese } & 《南水北调》 \\
\hline & (South-to-North Water Transfers and Water Science \& Technology) \\
\hline & 《气象》 \\
\hline & (Meteorological Monthly) \\
\hline & 《节水灌溉》 \\
\hline & (Water Saving Irrigation) \\
\hline \multirow[t]{3}{*}{ Korean } & 《한국농림기상학회지》 \\
\hline & (Korean Journal of Agricultural and Forest Meteorology) \\
\hline & Journal of the Korea Disaster Prevention Association \\
\hline Spanish & Tecnología y Ciencias del Agua \\
\hline \multirow[t]{2}{*}{ Portuguese } & Estudos Avançados \\
\hline & Pesquisa Agropecuária Brasileira \\
\hline
\end{tabular}

Among the 173 journal articles that cited FWCA published articles, 35 articles cited two, or more than two, FWCA articles, while 138 articles cited one FWCA article. Nineteen out of the 35 articles $(54.2 \%)$ were authored by one or more FWCA affiliated members. 
Journal of Applied Communications, Vol. 102, Iss. 1 [2018], Art. 6

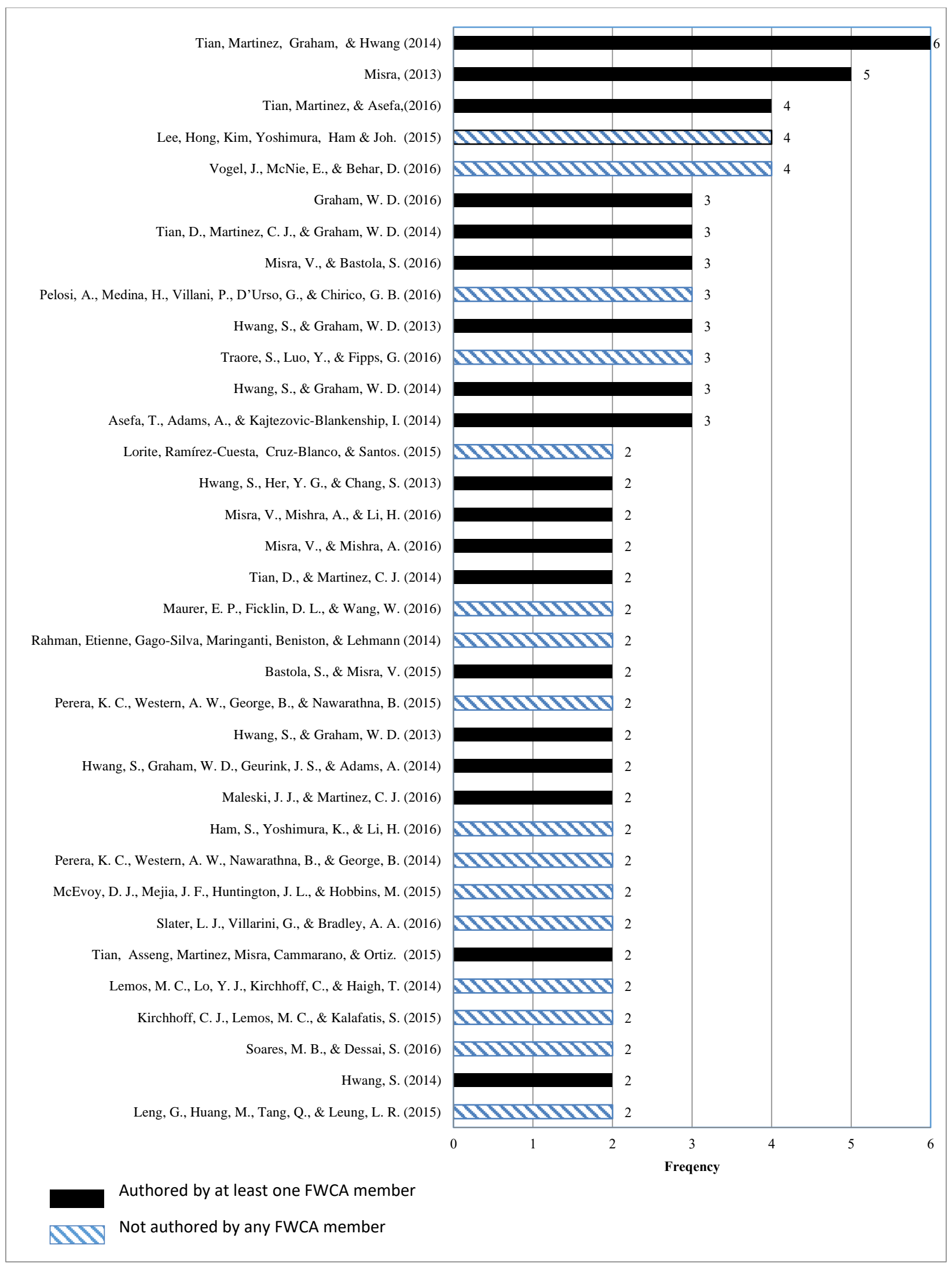

Figure 2: Journal articles citing two or more FWCA published articles 


\section{Conclusion and Recommendations}

The results of this study provide several key implications and future directions for both research and practice. The goal of this study was to investigate the impact of scientist-stakeholder partnership/self-directed organizations. This type of organization engages in science communication through journal articles in which members provide their scientific expertise and skills, with the goal of educating audiences about a scientific issue such as climate change. However, this type of organization often faces challenges in communicating effectively and in having an impact. This study specifically looked at one such organization, the Florida Water and Climate Alliance, utilizing the innovative methodology of citation analysis to examine the research productivity and citation impact of the organization's members as a method of assessing communication effectiveness and reputation.

The findings of this study demonstrated that the members of FWCA have been active in publishing scholarly articles since the establishment of the organization in 2012. The majority of the articles published have been cited in one or more journal articles, books, dissertations, theses, and proceedings. Most of the journals that have cited FWCA articles were written in the English language. A few foreign language journals have also been found to reference FWCA member published articles. Cited by foreign language journals indicated international impact and exposure of not only local, national, but international acknowledgment (Moed, 2006). Many articles that have cited FWCA articles, especially those that have cited more than two of them, were authored by FWCA members, meaning the members tended to cite FWCA members more than other scholars in the field. Unlike self-citation, which can be seen as a negative, when it comes to an organization with the goal of disseminating scientific information centered in a specific domain, this pattern of citation may be beneficial. This finding suggests that affiliation with a scientistbased organization focused on a specific issue that exhibits such a citation pattern may enhance citation counts of members and help create a body of literature around the organization's interest areas.

In addition, this study demonstrated the use of citation analysis as a method of evaluating the communication effectiveness of scientist-stakeholder partnerships/self-directed organizations. As these types of organizations are formed mainly by scientists, research productivity and citation impact are some of the most significant indicators of organizational reputation and effectiveness (Vidaver-Cohen, 2007). Before these organizations reach their ultimate level of general awareness, research productivity and citation impact can be assessed to determine how effective the organization is in communicating its members' scientific output. Goehlert (1979) suggested five metrics that could be used to look at citation impact: "(a) the form of publications cited, (b) the subject field distribution, (c) the languages used, (d) the age of the literature, and (e) the identification of significant sources, such as core journals" (p. 185). This study added the additional metric of citations among the members of the organization. This study showed that a large portion of the citations of FWCA member published articles were by other FWCA members. This suggests that members of scientist stakeholder partnerships often cite each other's work since one of the benefits of belonging to such organizations is to see what others in the field are doing. Further, group members may engage in citing each other in an attempt to build the reputation of the organization itself, suggesting that member citation of each other's work is a useful metric to evaluate the impact of such organizations.

For organizations like FWCA, whose members are already publishing in academic

publications, there are additional opportunities to further extend the reach and reputation of the 
organization as a whole as a collaborative partner and a source for expert, scientifically based information. As such organizations seek to communicate their science-based messages with larger audiences, it might be valuable to invest some resources in developing and promoting their identity, core messages and visibility with previously identified key audiences. This might include developing an informational package that could include media releases, member bios, key accomplishments, highlights from previous workshops, additional, and more widely disseminated, white papers based on research, key trends or takeaways from members' research/workshop presentations, infographics, state of the science briefings for leaders and policymakers. While it is challenging for self-directed organizations to find the resources to hire a full-time agricultural communicator, it might be possible to find enough resources to hire one as a freelancer. It is recommended that such organizations look for ways to find professional communication expertise to assist them in further developing their communication efforts by creating a reputation and enhancing materials for external audiences.

For future research, other activities such as workshops, presentations and webinars should be analyzed to investigate the translational communications efforts of scientist stakeholder partnerships/self-directed organizations. In addition, evaluating the media visibility of the organization can benefit the understanding of the organization's reputation and its communication effectiveness. Researchers can assess the mention or coverage of such an organization on print media, television news, or social media. These assessments can be analyzed quantitatively, such as counting the number of mentions. Qualitative analysis can also be used to identify the themes from the coverage of such organizations.

Lange et al. (2011) summarized a three-dimensional organizational reputation measurement. Based on this measurement, researchers can examine certain organization stakeholders' (e.g. organization members, other scientists in the field, policy-makers, target consumers) opinions about whether or not they recognize or are aware of an organization, what their perceptions about this organization consist of, and their favorability toward the organization. Such research questions will help agriculture and natural resource self-directed organizations to better understand if they are communicating their missions and goals effectively to their stakeholders, and how to strategically plan future organizational activities.

A limitation of this study is that the citation analysis was conducted on one organization. This was due to the fact that the study was essentially testing the use of a methodology, citation analysis, that has not been used to assess aspects of organizational reputation in the agricultural communications domain. Further, such organizations differ greatly in scope, membership and disciplinary characteristics, making direct comparison difficult.

For agricultural communications practitioners working in the science communications framework of disseminating "science-based" communication to diverse lay audiences, this study is significant in that it shows the advantages and limitations of relying on the traditional academic concept of "disseminating broader societal impacts." Scientists see those broader impacts in terms of journal article publications, primarily, which can be effective in informing the scientific community, but may have challenges in terms of achieving goals to inform practice and policymaking. The findings of this study show the need for these organizations to engage in more collaboration, more communications effectiveness achieved through engaging experienced agricultural communications practitioners and more agricultural communications research examining how to advance science related to controversial ANR issues.

Agricultural scientists of all types have a long tradition of using academic publication as a way of signaling that recommended practices are evidence-based and therefore credible and to be 
trusted. We need to better understand how this signaling operates in terms of communications effectiveness around issues, so as to inform practice with respect to controversial agricultural and natural resource issues, including climate variability and change, GMOs and animal agriculture.

Banker, R. D., Field, J. M., Schroeder, R. G., \& Sintia, K. K. (1996). Impact of work teams on manufacturing performance: A longitudinal field study. Academy of Management Journal, 39(4), 867-890. doi:10.2307/256715

Barker, J. R. (1993). Tightening the iron cage: Concertive control in self-managing teams. Administrative Science Quarterly, 408-437. doi:10.2307/2393374

Barnett, M. L., Jermier, J. M., \& Lafferty, B. A. (2006). Corporate reputation: The definitional landscape. Corporate Reputation Review, 9(1), 26-38. doi.org/10.1057/palgrave.crr.1550012

Borokhovich, K. A., Bricker, R. J., Brunarski, K. R., \& Simkins, B. J. (1995). Finance research productivity and influence. The Journal of Finance, 50(5), 1691-1717. doi:10.1111/j.1540-6261.1995.tb05193.x

Boykoff, M. T., \& Boykoff, J. M. (2007). Climate change and journalistic norms: A case-study of US mass-media coverage. Geoforum, 38(6), 1190-1204. doi.org/10.1016/j.geoforum.2007.01.008

Brulle, R. J., Carmichael, J., \& Jenkins, J. C. (2012). Shifting public opinion on climate change: An empirical assessment of factors influencing concern over climate change in the US, 2002-2010. Climatic Change, 114(2), 169-188. doi.org/10.1007/s10584-012-0403-y

Carter, S. M. (2006). The interaction of top management group, stakeholder, and situational factors on certain corporate reputation management activities. Journal of Management Studies, 43(5), 1145-1176. doi.org/10.1111/j.1467-6486.2006.00632.x

Center for Science and Democracy. (2016). Scientist-Community Partnerships: A scientist's guide to successful collaboration. Retrieved from http://www.ucsusa.org/sites/default/files/attach/2016/04/ucs-scientist-communitypartnerships-2016.pdf

Clarivate Analytics (2016). Web of Science. [Thomson Reuter Website]. Retrieved from http://ipscience.thomsonreuters.com/product/web-ofscience/?utm_source=false\&utm_medium $=$ false\&utm_campaign=false

Cockrel, J. (1997). Introduction to Public Policy Education. Retrieved from http://www2.ca.uky.edu/agcomm/pubs/ip/ip18/ip18.pdf. University of Kentucky Cooperative Extension Service.

Daft, R. L., Bettenhausen, K. R., \& Tyler, B. B. (1993). Implications of top managers' communication choices for strategic decisions. In G. P. Huber \& W. H. Glick (Eds.), Organizational Change and Redesign: Ideas and Insights for Improving Performance (112-146). Oxford: Oxford University Press.

Fielding, M. (2006). Effective communication in organizations. Cape Town: Juta \& Co.

Gioia, D. A., Schultz, M., \& Corley, K. G. (2000). Organizational identity, image, and adaptive instability. Academy of Management Review, 25(1), 63-81. doi:10.2307/259263

Goehlert, R. (1979). A citation analysis of international organization: The use of government documents. Government Publications Review (1973), 6(2), 185-193. doi.org/10.1016/0093-061X(79)90060-1

Grehan, A., Long, R., Deegan, B. \& Ó Cinneide, M. (2003). The Irish Coral Task Force and Atlantic Coral Ecosystem Study: Report on Two Deep-Water Coral Conservation 
Stakeholder Workshops held in Galway in 2000 and 2002", Marine Environment and Health Series No. 11, Marine Institute 2003

Highhouse, S., Brooks, M. E., \& Gregarus, G. (2009). An organizational impression management perspective on the formation of corporate reputations. Journal of Management, 35(6), 1481-1493. doi:10.1177/0149206309348788

Jackson, K. T. (2004). Building reputational capital. New York, Oxford University Press.

Johnson, B., \& Christensen, L. B. (2012). Educational research: Quantitative, qualitative, and mixed approaches. Thousand Oaks, Calif: SAGE Publications.

Kauffeld, S. (2006). Self-directed work groups and team competence. Journal of Occupational and Organizational Psychology, 79(1), 1-21. doi.org/10.1348/096317905X53237

Kern, K., \& Bulkeley, H. (2009). Cities, Europeanization and multi-level governance: Governing climate change through transnational municipal networks. JCMS: Journal of Common Market Studies, 47(2), 309-332. doi:10.1111/j.1468-5965.2009.00806.x

Lange, D., Lee, P. M., \& Dai, Y. (2011). Organizational reputation: A review. Journal of Management, 37(1), 153-184. doi:10.1177/0149206310390963

Love, E. G., \& Kraatz, M. (2009). Character, conformity, or the bottom line? How and why downsizing affected corporate reputation. Academy of Management Journal, 52(2), 314335. doi.org/10.5465/amj.2009.37308247

Manz, C. C., \& Sims, H. P. (1995). Business without bosses: How self-managing teams are building high-performing companies. New York, John Wiley \& Sons, Inc.

Meadow, A. M., Ferguson, D. B., Guido, Z., Horangic, A., Owen, G., \& Wall, T. (2015). Moving toward the deliberate coproduction of climate science knowledge. Weather, Climate, and Society, 7(2), 179-191. doi.org/10.1175/WCAS-D-14-00050.1

Meho, L. I. (2006). The rise and rise of citation analysis. Physics World, 20(1). 1-15. Retrieved from https://arxiv.org/abs/physics/0701012

Moed, H. F. (2006). Citation analysis in research evaluation (Vol. 9). Springer Science \& Business Media.

Park, J., Lee, H. and Kim, S. (2014). Corporate social responsibilities, consumer trust and corporate reputation: South Korean consumers' perspective. Journal of Business Research, 67(3). 295-302. doi.org/10.1016/j.jbusres.2013.05.016

Pfau, M., Holbert, R., Szabo, E., \& Kaminski, K. (2002). Issue-advocacy versus candidate advertising: Effects on candidate preferences and democratic process. Journal of Communication, 52(2), 301-315. doi.org/10.1111/j.1460-2466.2002.tb02546.x

Quinn, J. B. (1992), Intelligent Enterprise: A Knowledge and Service Based Paradigm for Industry. New York, NY, Free Press.

Ramsden, P. (1994). Describing and explaining research productivity. Higher Education, 28(2), 207-226. Retrieved from https://www.jstor.org/stable/3447753?seq=1\#page_scan_tab_contents

Rhee, M., \& Valdez, M. E. (2009). Contextual factors surrounding reputation damage with potential implications for reputation repair. Academy of Management Review, 34(1), 146168. doi.org/10.5465/amr.2009.35713324

Rindova, V. P., Williamson, I. O., Petkova, A. P., \& Sever, J. M. (2005). Being good or being known: An empirical examination of the dimensions, antecedents, and consequences of organizational reputation. Academy of Management Journal, 48(6), 1033-1049. doi.org/10.5465/amj.2005.19573108 
Robinson, L. M., \& Adler, R. D. (2011). Business research in eight business disciplines. Journal of College Teaching \& Learning, 1(2), 69-80. doi.org/10.19030/tlc.v1i2.1916

Schuett, M. A., Selin, S. W., \& Carr, D. S. (2001). Making it work: Keys to successful collaboration in natural resource management. Environmental Management, 27(4), 587593. doi.org/10.1007/s002670010172

Serenko, A., \& Bontis, N. (2004). Meta-review of knowledge management and intellectual capital literature: Citation impact and research productivity rankings. Knowledge and Process Management, 11(3), 185-198. doi.org/10.1002/kpm.203

Sinclair, J., \& Irani, T. (2005). Advocacy advertising for biotechnology: The effect of public accountability on corporate trust and attitude toward the ad. Journal of Advertising. 34: 59-73. doi.org/10.1080/00913367.2005.10639203

The Florida Water and Climate Alliance (2016). The Florida Water \& Climate Alliance (FloridaWCA). Retrieved from http://Floridawca.org/

Vidaver-Cohen, D. (2007). Reputation beyond the rankings: A conceptual framework for business school research. Corporate Reputation Review, 10(4), 278-304. doi.org/10.1057/palgrave.crr.1550055

Vine, R. (2006). Google scholar. Journal of the Medical Library Association, 94(1), 97. Retrieved from https://www.ncbi.nlm.nih.gov/pmc/articles/PMC1324783/

Vörösmarty, C. J., Green, P., Salisbury, J. \& Lammers, R. (2000). Global water resources: Vulnerability from climate change and population growth. Science 289 (5477), 284-288. doi:10.1126/science.289.5477.284

Washington, M., \& Zajac, E. J. (2005). Status evolution and competition: Theory and evidence. Academy of Management Journal, 48(2), 282-296. doi.org/10.5465/amj.2005.16928408

Wheeler, T., \& von Braun, J. (2013). Climate change impacts on global food security. Science 341(6145), 508-513. doi:10.1126/science.1239402

\section{ABOUT THE AUTHORS}

Shuyang Qu is an assistant professor in the Department of Agricultural Education and Studies at Iowa State University.

Tracy Irani is a professor and the chair of the Department of Family, Youth and Community Sciences at University of Florida.

Angela B. Lindsey is an assistant professor in the Department of Family, Youth and Community Sciences at University of Florida 